\title{
Influence of prerequisite concepts understanding and mathematical communication skills toward student's mathematical proving ability
}

\author{
Ellis Salsabila ${ }^{1^{*}}$ \\ ${ }^{1}$ Mathematics Education Program, Universitas Negeri Jakarta, Indonesia \\ *Corresponding Author. E-mail: ellissalsabila@yahoo.com
}

\begin{tabular}{|c|c|}
\hline ARTICLE INFO & ABSTRACT \\
\hline $\begin{array}{l}\text { Keywords: } \\
\text { Mathematical proving } \\
\text { ability } \\
\text { Prerequisite concepts } \\
\text { understanding } \\
\text { Mathematical } \\
\text { communication skills }\end{array}$ & $\begin{array}{l}\text { This study aims to describe the influence of prerequisite concepts understanding and mathe- } \\
\text { matical communication skills on the mathematical proving ability of Mathematics Education } \\
\text { Program students in the Faculty of Mathematics and Science, State University of Jakarta (FMIPA } \\
\text { UNJ). The method used in this study was a survey and correlational techniques. The study } \\
\text { population was all students of the Mathematics Education Program FMIPA UNJ in } 2018 \text {. The } \\
\text { study sample was taken with a simple random sampling technique, there were } 50 \text { students in } \\
\text { total. In this study, the dependent variable was mathematical proving ability ( } Y \text { ) and the } \\
\text { independent variables were the prerequisite concepts understanding }\left(X_{1}\right) \text { and mathematical } \\
\text { communication skills }\left(X_{2}\right) \text {. This study based on the inferential statistical analysis of research data } \\
\text { by using multiple regression analyses to test the effect of independent variables on the depen- } \\
\text { dent variables. The results obtained were: } 1 \text { ) the prerequisite concepts understanding had a } \\
\text { positive effect and significant on students' mathematical proving ability, } 2 \text { ) mathematical } \\
\text { communication skills had a positive effect and significant on students' mathematical proving } \\
\text { ability, and 3) prerequisite concepts understanding and mathematical communication skills } \\
\text { simultaneously had a positive effect and significant on mathematical proving ability with effect } \\
\text { size of } 69.3 \% \text {. }\end{array}$ \\
\hline
\end{tabular}

Penelitian ini bertujuan untuk memperoleh informasi tentang pengaruh pemahaman prerequisite concepts dan kemampuan komunikasi matematis terhadap kemampuan membuktikan matematis mahasiswa Pendidikan Matematika di Fakultas Matematika dan IImu Pengetahuan Alam Universitas Negeri Jakarta (FMIPA UNJ). Metode yang digunakan dalam penelitian ini adalah metode survei dan teknik korelasional. Populasi penelitian adalah seluruh mahasiswa Program Studi Pendidikan Matematika FMIPA UNJ tahun 2018. Sampel penelitian diambil dengan teknik simple random sampling sebanyak 50 mahasiswa. Variabel terikat dalam penelitian ini adalah kemampuan membuktikan matematis $(Y)$ dan variabel bebasnya adalah pemahaman prerequisite concepts $\left(X_{1}\right)$ dan kemampuan komunikasi matematis $\left(X_{2}\right)$. Penelitian ini berdasarkan analisis statistik inferensial atas data penelitian dengan menggunakan analisis regresi ganda untuk menguji pengaruh variable-variabel bebas terhadap variabel terikat. Hasil yang diperoleh adalah: 1) pemahaman prerequisite concepts berpengaruh positif dan signifikan terhadap kemampuan pembuktian matematis mahasiswa, 2) kemampuan komunikasi matematis berpengaruh positif dan signifikan terhadap kemampuan pembuktian matematis mahasiswa, 3) pemahaman prerequisite concepts dan kemampuan komunikasi matematis secara bersama-sama (simultan) memberikan pengaruh positif dan signifikan terhadap kemampuan pembuktian matematis mahasiswa dengan besar pengaruh sebesar Scan me $69,3 \%$.

This is an open access article under the CC-BY-SA license

\section{How to Cite:}

Salsabila, E. (2019). Influence of prerequisite concepts understanding and mathematical communication skills toward student's mathematical proving ability. PYTHAGORAS: Jurnal Pendidikan Matematika, 14(1), 46-55. doi: https://doi.org/10.21831/pg.v14i1.25067 


\section{INTRODUCTION}

The aims of mathematics teaching in higher education is to provide students with mathematical knowledge which includes facts, concepts, principles, patterns, and procedures, as well as the skills to form reasoning/logical thinking that can be used in the mathematics study itself, other subjects, and also in daily life. This is in accordance with the curricular objectives of mathematics teaching, thus students will be able to: (1) have mathematical knowledge and skills to solve mathematical problems themselves, practical use in other subjects and in daily life and for further study; (2) understand the relationships of mathematics parts; (3) have the ability to create analysis, synthesis, and conclusions; (4) have attitudes and habits of thinking logically, critically, systematically, carefully, diligently, and responsibly, (5) respect and absorb the beauty of mathematical concepts, structures, and patterns (Ruseffendi, 2006).

One kind of thinking skills that are being trained during mathematics learning is the higher-order thinking skills (Apino \& Retnawati, 2017; Jailani, Sugiman, \& Apino, 2017; Retnawati, Djidu, Kartianom, Apino, \& Anazifa, 2018), which is the ability to think critically and creatively. Critical thinking skills include analyzing, synthesizing and evaluating (Halpern, 2001; Nugraha \& Mahmudi, 2015), meanwhile creative thinking skills include problem-solving, proving, and creating (Ülger, 2016; Sariningsih \& Herdiman, 2017). Thus, proving skill is one kind of higher-order thinking skill that is not easy and fast to be mastered by students.

Based on the author's personal experience as a lecturer in a mathematics education program, most students are reluctant to work with proof problems, namely proving the existing or new mathematical statements or traits to be discovered. Students prefer to excel in their skills in counting and applying concepts to find solutions to problems. According to Moore (1994) who had identified the weaknesses and difficulties of students in mathematics proving, there are seven types of difficulties, as follows: (1) students cannot express definitions with their language; (2) students' concept understanding intuition is low; (3) to finish a proving problems, concept images is not enough; (4) students cannot and do not want to make their examples; (5) students do not know how to use definitions to obtain a comprehensive proof structure; (6) students cannot understand and use the mathematical language and notation; and (7) students do not know how to start proving. During the initial stage, understanding evidence is found to be less interesting because it deals with symbols, variables and logical statements, rather than dealing with numbers that are usually regarded as mathematical characters. This fact is one reason why students are uninterested to learn evidence proving in mathematics. Another reason is that proving is known to be more difficult and not important.

Many benefits can be obtained from proving learning, such as to train the logically thinking in learning mathematics. According to Stylianides, Stylianides, and Shilling-Traina (2013), evidence or proving is at the heart of mathematics and mathematical thinking. Meanwhile, according to Arnawa (2006), proving makes mathematics unique and different from other scientific disciplines. Proving is the main characteristic of mathematical activities and is a key component in learning mathematics. The National Agency for Educational Standards (BSNP, 2006) states that learning mathematics intends to enable students in having the ability to use reasoning on patterns and traits, to perform mathematical manipulations in making generalizations, to compile evidence, and to explain mathematical ideas and statements. Epp (2003) also states that one of the best approaches to develop students' abstract thinking skills is through meaningful involvement in constructing and completing mathematical proving. There are several reasons why proving teaching is needed: (1) proving is an integral part of mathematics; (2) can be used for verification and discovery of facts; (3) can be used to develop students' logical and critical thinking skills and; and (4) to accelerate and enhance students' mathematical understanding (Yerison, 2011).

Mathematics is full of definitions, entries, theorems, and concepts that involve the process of proving. To understand the concepts in mathematics requires students' ability to understand and demonstrate the process of mathematical proving (Zaslavsky, Nickerson, Stylianides, Kidron, \& Winicki-Landman (2012). Therefore, mathematical proving ability in learning mathematics is important to be possessed by students to master mathematics itself. By having mathematical proving ability, students are asked to demonstrate their ability in proving through the determination and preparation of procedural steps in mathematical proving. Students show the process of it step-by-step by expressing their reasons and arguments at each step they choose. Students are also asked to be able to compile the proving process using their own words, arrange it logically and systematically by writing the facts and coupling their relevance to the conclusions to be reached. Hence evidence could be formed on the mathematical statement. 
According to Arnawa (2006), to be able to do mathematical proving properly, students are required to have prerequisite knowledge, such as mathematical logic and proving method. Mathematical logic provides a basis for logic in arguing or drawing conclusions on mathematical statements, meanwhile proving methods provide ways that can be used to prove the truth of a mathematical statement. The proving method, which includes definition, structure, and procedure, needs to be understood by students as a basis to determine and arrange the appropriate steps of mathematical proving.

Besides mastering the prerequisite concepts, to be able to work with mathematical proof problems also requires other abilities, such as mathematical communication skills. Mathematical communication skills according to Sumarmo (2005) are one of the five basic mathematical ability standards that students must have alongside the ability of concepts understanding, mathematical problem solving, mathematical reasoning, and mathematical connection skills. Through mathematical communication skills, students can communicate their mathematical ideas, organize, consolidate, and integrate their mathematical thinking both orally and in text.

Therefore, it is necessary to research these two abilities toward mathematical proving ability of students. This study aims to obtain the information regarding the influence of prerequisite concepts understanding and mathematical communication skills on mathematical proving ability of Mathematics Education Program Students in Faculty of Mathematics and Science, State University of Jakarta (FMIPA UNJ).

\section{METHOD}

\section{Design, Population, and Sample}

This was a quantitative research with survey methods and correlational techniques with two independent variables and one dependent variable as shown in Figure 1.

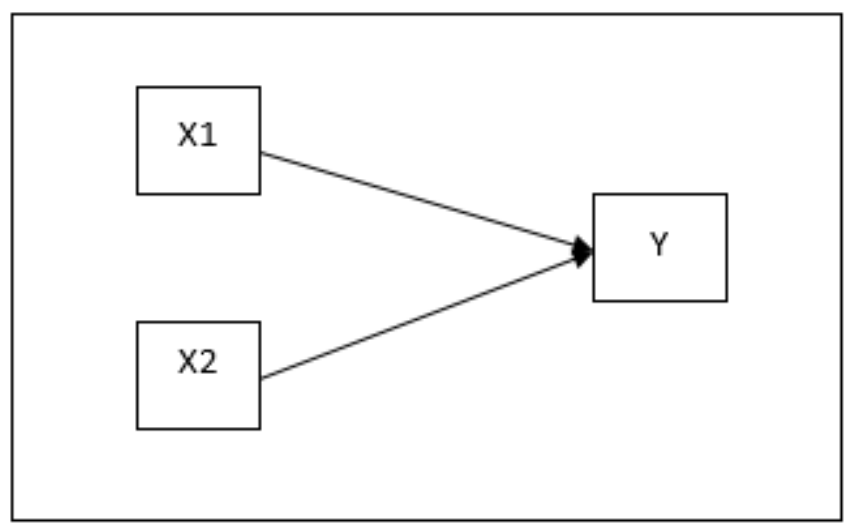

Figure 1. Study Desing; X1: Prerequisite Concepts Understanding; X2: Mathematical Communication Skills; Y: Mathematical Proving Ability.

This research was conducted at the Mathematics Education Program of FMIPA UNJ, with all students of the Mathematics Education Study Program FMIPA UNJ in 2018 as the target population. As much as 50 students were taken as the study samples by a simple random sampling technique.

The preparation of the instrument was carried out from June to August 2018, meanwhile, the data collection was conducted from September to October 2018. After the sample collection was done, data analysis was done during November and December 2018. The collected data were in the form of mathematical proving abilities test results which was done during the Real Analysis I lecture, the result of prerequisite concepts test, and also the result of the mathematical communication skills test.

\section{Research Instrument}

The instruments used in this study consisted of three written test instruments, namely: mathematical proving abilities test, prerequisite concepts understanding test, and mathematical communication skills test. The instrument for mathematical proving abilities test was an essay test covering the material aspects of Real Analysis I and mathematical proving ability aspects, which was consisted of 6 items. The aspects of the mathematical proving abilities that were measured: (1) identifying the premise and conclusions; (2) organizing and manipulating known facts to obtain conclusions; (3) using the proofing methods; (4) creating connections between known facts and 
conclusion; (5) completing the reasons for each proofing steps; and (6) compiling the evidence logically and systematically.

For prerequisite concepts understanding tests, the instrument was a multiple-choice test consisting of 35 items. The questions were created to cover the aspects of prerequisite concepts understanding, which was mathematical logic concepts and mathematical proofing methods. Those aspects were: (1) explaining the concept; (2) presenting examples; (3) interpreting; (4) classifying; (5) summarizing; (6) comparing; and (7) concluding.

Meanwhile, the instrument of mathematical communication skills test was in the form of a mathematical essay consisting of 12 items, which was arranged to cover the aspects of mathematical communication skills. The aspects of mathematical communication skills that were measured: (1) explaining ideas, mathematical concepts, mathematical situations, and mathematical problems; (2) writing contextual problems that are given in the form of equations or mathematical models (mathematical expressions); (3) describing contextual problems given in the form of graphs, charts, tables, or diagrams; (4) interpreting ideas or mathematical concepts given in the form of graphs, charts, tables, diagrams, equations or mathematical models into sentences; and (5) presenting ideas or mathematical concepts into other forms.

\section{Validity and Reliability of Instruments}

The validity of the instrument was carried by examining the suitability of the items on the indicators of the measured variables (content validity). The content validity of each instrument was proven by asking the experts to judge the suitability of the items with the indicators of the measured variables. The experts were three lecturers of the Mathematics and Mathematics Education Study Program at FMIPA UNJ. Each expert advised the instruments and the researcher made revisions based on the advice of each expert. The instrument was declared valid if there were no more revisions and each expert declares that the instrument was appropriate.

Furthermore, the instrument reliability estimation was carried out to determine the consistency of the instrument. The reliability estimation of essay test instruments was carried out using the Alpha Cronbach correlation coefficient formula. The reliability coefficient of the mathematical proving ability test instrument was 0.716 , while the reliability coefficient of the mathematical communication skills test instrument was 0.739 . As for the reliability estimation of the multiple-choice instrument, tests were carried out using the Kuder-Richardson 20 formula (KR-20). From the calculation results, it was obtained that the reliability coefficient of the prerequisite concepts understanding test instrument was 0.79 . Thus the three test instruments had high reliability.

\section{Statistical Hypothesis}

The statistical hypotheses tested in this study were:

1. $H_{0}: \beta_{1}=\beta_{2}=0 \quad$ There was no significant linear relationship between independent variables and mathematical proving ability.

$H_{1}$ : there is at least one $\beta_{k} \neq 0, k=1,2$ There was a significant linear relationship between independent variables and mathematical proving ability.

2. $H_{0}: \beta_{1} \leq 0$ There was a negative (or nothing) linear relationship between prerequisite concepts understanding and mathematical proving ability.

$H_{1}: \beta_{1}>0$ There was a positive linear relationship between prerequisite concepts understanding and mathematical proving ability.

3. $H_{0}: \beta_{2} \leq 0$ There was a negative (or nothing) linear relationship between mathematical communication skills understanding and mathematical proving ability.

$\mathrm{H}_{1}: \beta_{2}>0$ There was a positive linear relationship between mathematical communication skills understanding and mathematical proving ability.

\section{Data Analysis}

Descriptive analysis and inferential analysis were conducted. Descriptive analysis was conducted to determine the tendency to centralize and disseminate data, while inferential analysis was conducted to test the research hypothesis. Boxplots were used for the descriptive analysis and multiple regressions were used for the inferential analysis. Before analyzing the data, a normality test, homogeneity test, and independence test were carried out. All tests were mentioned above were analyzed with the SPSS software in significance level 0.05 . 


\section{RESULT AND DISCUSSION}

\section{Data Description}

Student scores were obtained from the results of prerequisite concepts understanding test, mathematical communication skills test, and mathematical proving ability test of 50 samples. Table 1 presented the descriptive statistics from the results of these tests.

Table 1. Descriptive Data of Prerequisite Concepts Understanding (PCU), Mathematical Communication Skills (MCS), and Mathematical Proving Ability (MPA).

\begin{tabular}{llll}
\hline & PCU & MCS & MPA \\
\hline$n$ & 50 & 50 & 50 \\
Min. score & 57 & 55 & 23 \\
Max. score & 89 & 83 & 73 \\
Range & 32 & 28 & 50 \\
Average & 73.18 & 69.38 & 46.66 \\
Variance $\left(s^{2}\right)$ & 61.46 & 41.26 & 159.21 \\
Standard deviation $(s)$ & 7.84 & 6.42 & 12.62 \\
First quartile $\left(\mathrm{Q}_{1}\right)$ & 66.75 & 65 & 36.5 \\
Median & 73 & 69.5 & 47 \\
Third quartile $\left(\mathrm{O}_{3}\right)$ & 79.25 & 73.5 & 57 \\
Interquartile Range & 13 & 9 & 21 \\
Skewness & -0.004 & -0.018 & 0.057 \\
Kurtosis & -0.662 & -0.383 & -0.867 \\
\hline
\end{tabular}

It was shown that the average score of the mathematical proving ability test results was much lower than average scores of the prerequisite concepts understanding and mathematical communication skills test results. This showed that the sample students still have difficulties in working on their mathematical proving ability test. It was also found that the standard deviation of the score of mathematical proving ability test results is higher than the other two tests, which indicated that the score of mathematical proving ability test was more diverse than the other two. The boxplot diagrams for the three test results which were obtained by SPSS were presented in Figure 2 .

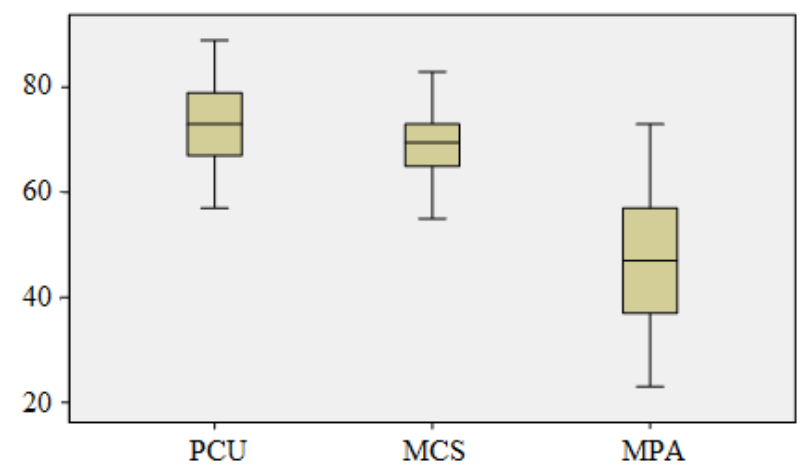

Figure 2. The Boxplot Diagrams of Prerequisite Concepts Understanding (PCU), Mathematical Communication

Skills (MCS), and Mathematical Proving Ability (MPA).

In Figure 2, $Q_{1}$ was shown by the bottom horizontal line of a rectangle, $Q_{2}$ was indicated by a horizontal line on the inside of a rectangle, and $\mathrm{Q}_{3}$ was indicated by a horizontal line on the top of a rectangle. In prerequisite concepts understanding and mathematical proving ability data, it could be seen that the $Q_{2}$ values were located in the middle of the box, meaning that the data were spread under and above the median. Whereas in the mathematical communication skills data, the $Q_{2}$ value is closer to the $Q_{3}$ value, which means that the data was more centered above the median and more diffuse under the median. The diagram also shows that the three test data have the same length at the bottom and top of the box, showing that the data distribution was symmetrical. 


\section{Precondition Data Analysis Test}

The normality test for the three data was conducted by the Kolmogorov-Smirnov test and the Shapiro-Wilk test. From the test of normality output of the three data, it was obtained that p-value $>0.05$, while the KolmogorovSmirnov test showed $p$-value $=0.2$. Meanwhile the Shapiro-Wilk test on prerequisite concepts understanding data obtained $p$-value $=0.807$, on mathematical communication skills data obtained $p$-value $=0.759$, and on mathematical proving ability data obtained $p$-value $=0.413$. Thus, all data showed $p$-value $>0.05$, meaning that all three data are normally distributed.

A normality test for regression errors was also conducted. Regression error was obtained from the score results difference of the mathematical proving ability test ( $Y$ observation) with the $Y$ model. The regression error normality test was done by the Kolmogorov-Smirnov test and the Shapiro-Wilk test. From the test of normality result with the Kolmogorov-Smirnov test, it was obtained that the $p$-value $=0.2$, while the Shapiro-Wilk test obtained $p$-value $=0.953$. Thus all data showed $p$-value $>0.05$, meaning that the regression error data were normally distributed. Test for regression error homogeneity was carried out with Levene's test. Regression error data were divided into five groups, which were distributed based on sequential numbers. From the results of the Levene's test, it was found that the $p$-value was $0.668>0.05$, meaning that the regression error data is homogeneous.

The conducted independence tests were including the autocorrelation test and multicollinearity test. The autocorrelation test was done to check whether the regression error was independent or not. From the results of the Durbin-Watson test for the regression equation model test, the statistical test value was 1.413 which was located between 1 and 3, meaning that the regression error was independent. Meanwhile, the multicollinearity test was conducted to check whether the independent variables were independent or that there was no multicollinearity. It was obtained that the VIF value of the prerequisite concepts understanding variable was 2.183 and the mathematical communication skills were 2.183 , thus both $\mathrm{VIF}<10$, indicating that the independent variables were independent or there was no multicollinearity.

\section{Statistical Hypothesis Test}

Multiple regression analysis was conducted to test the effect of independent variables on the dependent variable. The first step was to determine multiple linear regression equations of the mathematical proving ability for prerequisite concepts understanding and mathematical communication skills and also to determine the coefficient of regression equations. From the analysis result, it was obtained a linear regression equation of dependent variable mathematical proving ability $(Y)$ for the independent variables prerequisite concepts understanding $\left(X_{1}\right)$ and mathematical communication skills $\left(X_{2}\right)$ was $Y=-64.728+0.869 \times 1+0.689 \times 2$. The significance test of the regression equation coefficient was done to test the hypotheses: $H_{0}: \beta_{1} \leq 0$ vs. $H_{1}: \beta_{1}>0$ and $\mathrm{H}_{0}: \beta_{2} \leq 0$ vs. $\mathrm{H}_{1}: \beta_{2}>0$. Prerequisite concepts understanding variable coefficient showed that $t=4.522$ and $p$-value $=0.000 / 2=0.000<0.05$. Thus the $\mathrm{H}_{0}$ was rejected, meaning that the prerequisite concepts understanding has a positive effect on the mathematical proving ability. While the mathematical communication skills variable coefficient showed that $t=2.939$ with $p$-value $=0.005 / 2=0.0025<0.05$. Thus $\mathrm{H}_{0}$ was rejected, meaning that mathematical communication skills also have a positive effect on the mathematical proving ability.

The second step was the significance of multiple regression equations test. This test was conducted to test the hypotheses: $\mathrm{H}_{0}: \beta_{1}=\beta_{2}=0$ vs. $\mathrm{H}_{1}$ : there is at least one $\beta_{k} \neq 0, k=1,2$. From the ANOVA results, it was obtained that the $F=53.109$ and $p$-value $=0.000<0.05$, From the ANOVA results, it was obtained that the $F=53.109$ and $p$ value $=0.000<0.05$, thus $\mathrm{H}_{0}$ was rejected. This indicated that there was an influence of simultaneous prerequisite concepts understanding and mathematical communication skills towards mathematical proving abilities. While the coefficient of determination was indicated by $R$ square $=0.693$, which means that $69.3 \%$ variability of mathematical proving abilities $(Y)$ can be explained by prerequisite concepts understanding $\left(X_{1}\right)$ and mathematical communication skills $\left(X_{2}\right)$. It could also be assumed that simultaneous prerequisite concepts understanding and mathematical communication skills improved mathematical proving abilities by $69.3 \%$, while $30.7 \%$ was influenced by other factors.

The last step was the significance test of partial correlation coefficients. By controlling the influence of mathematical communication skills, the correlation between prerequisite concepts understanding and mathematical proving ability was $r=0.551$ and $p$-value $=0.000<0.05$. Thus the correlation was significant. Meanwhile, by 
controlling prerequisite concepts understanding, the correlation between mathematical communication skills and mathematical proving ability was $r=0.394$ and $p$-value $=0.003<0.05$, so the correlation was also significant.

\section{Discussion}

\section{The Effect of Prerequisite Concepts Understanding on Mathematical Proving Ability}

In this study, students' prerequisite concepts understanding had a positive effect on their mathematical proving ability, and that the correlation between prerequisite concepts understanding and mathematical proving abilities by controlling mathematical communication skills was significant. This happens because the prerequisite concepts understanding is students' cognitive ability to understand the underlying concepts in studying, processing or obtaining further concepts. In this study, the prerequisite concepts understanding is to understand the mathematical logic concepts and mathematical proving methods as a basis for being able to work with mathematical evidentiary problems. Mathematics is a hierarchically arranged science, which is a concept based on a previous concept and a concept that will underlie the next concept. Mathematics, as a science with deductive reasoning, relies on logic in the process of convincing the truth of a statement. Mathematical statements are generally in the form of logical sentences, thus proving the truth of mathematical statements is nothing but proving the truth of a logical sentence. The ability to master mathematical proving methods also needs to be possessed by students to be able to understand the theorems in mathematics and their proofs. Students also need to be able to show the process of evidence in every mathematical proof problem, because the proving method development was aimed to improve students' ability to understand the proving process and working on mathematical statements.

Therefore, the prerequisite concepts understanding empirically has been shown to have a positive influence on students' mathematical proving abilities. This means that the changes happening to students' mathematical proving abilities are also influenced by students' prerequisite concepts understanding. The better their prerequisite concepts understanding, the better their mathematical proving abilities. These results are in accordance with the opinion of Arnawa (2006) which states that to be able to make mathematical proof properly, students are required to have prerequisite knowledge, such as mathematical logic and mathematical proving methods.

\section{The Effect of Mathematical Communication Ability on Mathematical Proving Ability}

From the result was also found that mathematical communication skills had a positive effect on mathematical proving ability and that the correlation between mathematical communication skills and mathematical proving abilities by controlling prerequisite concepts understanding was significant. This is because mathematical communication skills are the core ability to communicate regarding mathematical elements or statements including facts, concepts, principles and mathematical procedures through explaining, writing, or discussing incomprehensible words. Mathematical communication skills include the ability to explain, compose arguments, interpret, connect, construct mathematical ideas or concepts into language or mathematical symbols, make conjectures, formulate definitions, statements and generalizations of mathematics. These characteristics of mathematical communication skills are also included in the characteristics of mathematical proving abilities, which is the ability to explain, organize and manipulate definitions, lemmas, mathematical theorems or statements, and the ability to construct logical steps, compile arguments to conclude statements.

Generally, mathematical proving abilities are the ability to convince the truth of mathematical statements, which are indicated by the ability to explain, show prove the truth of these mathematical statements in the form of writing, compiling or communicating the evidence. According to Hanna (Sabri, 2003), formal evidence has the following characteristics: (1) each definition, assumption, and underlying axiom system is stated explicitly; and (2) each step of proving the process is accompanied by deductive reasons. Regarding the acceptance of a theorem, Hanna (Hanna \& Jahnke, 1996) provides that formal evidence must contain convincing and accurate arguments. Characteristics in showing the proving process, such as being able to explicitly state a concept that used and can provide convincing reasons and arguments at each step of proving, are the characteristics of the mathematical communication process. It has been shown by the results of this study that students' mathematical communication skills have been tested to have a positive influence on students' mathematical proving abilities. This means that the changes happening to students' mathematical proving abilities are also influenced by students' mathematical 
Ellis Salsabila

communication skills. The better the students' mathematical communication skills, the better their mathematical proving abilities.

The Effect of Prerequisite Concepts Understanding and Mathematical Communication Skills on Mathematical Proving Ability

From the results of this study, it was found that there was an influence of simultaneous prerequisite concepts understanding and mathematical communication skills towards mathematical proving abilities. The influence of simultaneous prerequisite concepts understanding and mathematical communication skills on mathematical proving abilities was $69.3 \%$. This means that the change to the variable of mathematical proving abilities of $69.3 \%$ was because of the joint influence of both variables prerequisite concepts understanding and mathematical communication skills. In order to work with the problem of mathematical proving, students need to understand the concept of prerequisites first, after which students need to communicate their ideas regarding the problem of mathematical proving in the form of explaining and organizing these ideas using mathematical symbols, mathematical expressions or mathematical languages so that an acceptable process of evidence could be formed. The simultaneous prerequisite concepts understanding and mathematical communication skills influence the mathematical proving ability. These results were in accordance with the opinion of Selden and Selden (2003) that the ability of mathematical proving consists of the ability to construct evidence and the ability to validate evidence. The ability to construct evidence includes the ability to use methods of proof, definitions, entries, and theorems to show the truth of a statement in mathematics. Meanwhile, the ability to validate evidence includes the ability to criticize evidence. Validating evidence activities include: (1) reading a mathematical proving to determine the truth or error by testing the compatibility between the axiom system, premise, existing mathematical results (entries or theorems), with the flow of deductive reasoning; (2) completing proof; and (3) comparing the effectiveness of the evidence.

Thus, based on the results of this study, it has been shown empirically that the prerequisite concepts understanding and mathematical communication skills of students were proven to have a joint influence on the mathematical proving abilities of students. This means that the changes happening in students' mathematical proving abilities are simultaneously influenced by their prerequisite concepts understanding and mathematical communication skills.

\section{CONCLUSION}

Based on the results and discussion, it can be concluded that in Mathematics Education Program Students of FMIPA UNJ: 1) the prerequisite concepts understanding had a positive effect and significant on students' mathematical proving ability, 2) mathematical communication skills had a positive effect and significant on students' mathematical proving ability, and 3) prerequisite concepts understanding and mathematical communication skills simultaneously had a positive effect and significant on mathematical proving ability and both of these variables were able to explain $69.3 \%$ of students' mathematical proving ability, while $30.7 \%$ of students' mathematical proving ability was explained by other variables.

We suggest that educators (lecturers or teachers) pay full attention to students' prerequisite understanding and mathematical communication skills, so students could overcome their difficulties in carrying out mathematical proof. Both of these abilities must be trained to students, both through the learning process and given math assignments. For other researchers, we suggest investigating other factors that can affect students' mathematical proving ability, in addition to the two variables that have been examined in this study. Besides, it also required research and development of learning kits that could train the three variables that have been studied.

\section{REFERENCES}

Apino, E., \& Retnawati, H. (2017). Developing instructional design to improve mathematical higher order thinking skills of students. Journal of Physics: Conference Series, 812(1), 1-7. doi: http://doi.dx/10.1088/17426596/812/1/012100

Arnawa, I. M. (2006). Meningkatkan kemampuan pembuktian mahasiswa dalam aljabar abstrak melalui pembelajaran berdasarkan teori APOS [Improving the proving ability of students in abstract algebra through learning based on APOS theory] (Unpublished doctoral dissertation). Universitas Pendidikan Indonesia, Bandung. 
BSNP, (2006). Standar kompetensi dan kompetensi dasar SMA/MA [Competency standards and basic competencies for Senior High School/Islamic Senior High School]. Jakarta: Author.

Epp, S. S. (2003). The role of logic in teaching proof. The American Mathematical Monthly, 110(10), 886-899. doi: https://doi.org/10.1080/00029890.2003.11920029

Halpern, D. F. (2001). Assessing the effectiveness of critical thinking instruction. The Journal of General Education 50(4), 270-286. doi: http://doi.org/10.1353/jge.2001.0024

Hanna, G., \& N. Jahnke, (1996). Proof and proving. In A. J. Bishop, K. Clements, C. Keitel., J. Kilpatrick, \& C. Laborde (Eds.), International Handbook of Mathematics Education (pp 877-908). Dordrecht: Kluwer Academic Publishers.

Jailani, J., Sugiman, S., \& Apino, E. (2017). Implementing the problem-based learning in order to improve the students' HOTS and characters. Jurnal Riset Pendidikan Matematika, 4(2), 247-259. doi: https://doi.org/10.21831/jrpm.v4i2.17674

Moore, R. C. (1994). Making the transition to formal proof. Educational Studies in Mathematics, 27(3), 249-266. doi: https://doi.org/10.1007/BF01273731

Nugraha, T. S., \& Mahmudi, A. (2015). Keefektifan pembelajaran berbasis masalah dan problem posing ditinjau dari kemampuan berpikir logis dan kritis [The effectiveness of problem-based learning and problem posing in terms of the ability to think logically and critically]. Jurnal Riset Pendidikan Matematika, 2(1), 107 - 120. doi: https://doi.org/10.21831/jrpm.v2i1.7154

Retnawati, H., Djidu, H., Kartianom, K., Apino, E., \& Anazifa, R. D. (2018). Teachers'knowledge about higher-order thinking skills and its learning strategy. Problems of Education in the 21st Century, 76(2), 215-230. Retrieved from http://oaji.net/articles/2017/457-1524597598.pdf

Ruseffendi, E. T. (2006). Pengantar kepada membantu guru mengembangkan kompetensinya dalam pengajaran matematika untuk meningkatkan CBSA [Introduction to helping teachers develop competencies in teaching mathematics to improve CBSA]. Bandung: Tarsito.

Sabri, S. (2003). Prospective secondary school teachers' conceptions of mathematical proof in indonesia (Unpublished master's thesis). Curtin University of Technology, Perth.

Sariningsih, R., \& Herdiman, I. (2017). Mengembangkan kemampuan penalaran statistik dan berpikir kreatif matematis mahasiswa di Kota Cimahi melalui pendekatan open-ended [Developing the ability of statistical reasoning and mathematical creative thinking of students in the City of Cimahi through an open-ended approach]. Jurnal Riset Pendidikan Matematika, 4(2), 239-246. doi: https://doi.org/10.21831/jrpm.v4i2.16685

Selden, A., \& Selden, J. (2003). Validations of proof considered as texts: can undergraduates tell whether an argument proves a theorem? Journal for Research in Mathematics Education, 34(1), 4-36. doi: https://doi.org/10.2307/30034698

Stylianides, G. J., Stylianides, A. J. \& Shilling-Traina, L. N. (2013). Prospective teachers' challenges in teaching reasoning-and-proving. International Journal of Science and Mathematics Education, 11(6), 1463-1490. doi: https://doi.org/10.1007/s10763-013-9409-9

Sumarmo, U. (2005). Pengembangan berfikir matematika tingkat tinggi siswa SLTP dan SMU serta mahasiswa strata satu (S1) melalui berbagai pembelajaran. Laporan Penelitian Lembaga Penelitian Universitas Pendidikan Indonesia [Development of mathematical high-level thinking of junior and senior high school students and undergraduate students through a variety of learning. Research Report of Research Institute Universitas Pendidikan Indonesia]. Retrieved from http://penelitian.lppm.upi.edu/detil/675/pengembanganberfikir-matematik-tingkat-tinggi-siswa-sltp-dan-smu-serta-mahasiswa-strata-saru-(s1)-melalui-berbagaipendekatan-pembelajaran 
Ülger, K. (2016). The relationship between creative thinking and critical thinking skills of students. Hacettepe Üniversitesi Eğitim Fakültesi Dergisi (H. U. Journal of Education), 31(4), 695-710. doi: https://dx.doi.org/10.16986/HUJE.2016018493

Yerison. (2011). Peningkatan Kemampuan pembuktian dan kemandirian belajar matematik mahasiswa melalui pendekatan M-APOS [The improvement of students' proving ability and self-regulated learning through the M-APOS approach] (Unpublished doctoral dissertation). Universitas Pendidikan Indonesia, Bandung.

Zaslavsky, O., Nickerson, S.D., Stylianides, A. J., Kidron, I., \& Winicki-Landman, G. (2012). The need for proof and proving: mathematical and pedagogical perspectives. In G. Hanna \& M. de Villiers (eds.), Proof and proving in mathematics education: New ICMI Study Series 15 (pp. 215-229). Dordrecht: Springer. doi: https://doi.org/10.1007/978-94-007-2129-6 